\title{
Pengasuhan Anak Usia Dini dalam Hikayat Indraputra
}

\author{
Sigit Purnama ${ }^{\varpi_{1}}$, Laily Hidayati ${ }^{2}$ \\ Pendidikan Islam Anak Usia Dini, Universitas Islam Negeri Sunan Kalijaga Yogyakarta ${ }^{1}$ \\ Pendidikan Islam Anak Usia Dini, Institut Agama Islam Al Hikmah Tuban² \\ DOI: $10.31004 /$ obsesi.v4i2.391
}

\begin{abstract}
Abstrak
Hikayat Indraputra (HI) adalah salah satu karya sastra Melayu yang sangat populer. Jumlah naskahnya yang banyak dan telah diterjemahkan ke dalam tiga bahasa lain menunjukkan pentingnya naskah itu untuk dikaji dengan mendalam. Penelitian ini bertujuan untuk mengungkap model pengasuhan anak usia dini dalam naskah $\mathrm{HI}$, dengan menggunakan metode penelitian lingkaran fungsi Braginsky dengan beberapa indikator tertentu sebagai pedoman operasional. Fungsi yang dimaksud di sini adalah apa yang dituju oleh pengarang dan signifikansi teks-teks tertentu dalam keseluruhannya. Penelitian ini berusaha menemukan bentuk pengasuhan anak pada keluarga kerajaan yang hidup pada masa lampau, yang tentu terdapat banyak perbedaan lingkungan sosial budaya dengan bentuk pengasuhan pada masa sekarang. Penelitian ini menemukan bahwa, isi cerita yang mempunyai konteks pengasuhan anak usia dini yaitu bentuk pengasuhan yang diterapkan oleh Maharaja Bikrama Bispa kepada anaknya antara lain adalah ketika Maharaja Bikrama Bispa bersyukur dan bersukacita atas kelahiran, memberi nama yang baik, memberi perlindungan, mengenalkan agama, menjaga kebersihan, membahagiakan, dan mendoakan anak. Temuan atas indikator-indikator pengasuhan anak tersebut direduksi dari data inti aspek-aspek pengasuhan yaitu asuh, asih, dan asah.
\end{abstract}

Kata Kunci: hikayat indraputra; suntingan teks; analisis fungsi; pengasuhan anak usia dini.

\begin{abstract}
Hikayat Indraputra (HI) is a very popular Malay literary work. The large number of manuscripts that have been translated into three other languages shows the importance of the manuscript to be studied in depth. This study aims to uncover the model of early childhood parenting style in the HI text, using the Braginsky function circle research method with certain indicators as operational guidelines. The function referred to what is intended by the author and the significance of certain texts in its entirety. This study seeks to find the form of early childhood parenting style for the royal family who lived in the past, which of course there was so many differences in the socio-cultural environment with the form of parenting style in the present. This study found that, the contents of the story that have the context of early childhood parenting style as the form of parenting style that is applied by Maharaja Bikrama Bispa to his son, among others, is how Maharaja Bikrama Bispa grateful and rejoices at the birth of his son, he gave a good name and protection, introduces religion, preserves religion, safeguards clean, happy, and pray for his son. The findings on childhood parenting style indicators are deducted from the core data aspects of caregiving: fostering, loving, and stimulating.
\end{abstract}

Keywords: hikayat indraputra, text editing; function analysis; early childhood parenting style.

Copyright (c) 2020 Sigit Purnama, Laily Hidayati

$\triangle$ Corresponding author :

Email Address : sigit.purnama@uin-suka.ac.id (Yogyakarta, Indonesia)

Received 16 December 2019, Accepted 7 January 2020, Published 9 January 2020 


\section{PENDAHULUAN}

Bangsa Indonesia memiliki sejumlah peninggalan kebudayaan masa lampau. Di antaranya adalah peninggalan kebudayaan bangsa Melayu karena kebudayaan ini dikenal sebagai negara yang kaya dengan khazanah budaya peninggalan masa lampau dalam bentuk naskah dengan tulisan tangan yang tidak sedikit karena berkisar 8.000-10.000 naskah (Braginsky, 1998). Salah satunya adalah Hikayat Indraputra $(H I)$. Tercatat bahwa ada 30 buah naskah $H I$, yaitu 11 tersimpan di Leiden (8 di Universiteits-Bibliotheek dan 3 di Koninklijk Instituut voor de Taal-, Land- en Volkendunde), 7 di London (4 di Royal Asiatic Society, 2 di School of Oriental and African Studies, 1 di India Office Library), 3 di Cambridge (University of Cambridge), 3 di Paris (Bibliothèque Nationale), 2 di Jakarta (PNRI), 1 di Berlin (Preussische Staatsbibliothek), 1 di Brussel (Bibliothèque Royale), 1 di Kuala Lumpur (Dewan Bahasa dan Pustaka), dan 1 di Sri Lanka (Mulyadi, 1983). HI tidak hanya ditemukan dalam sastra Melayu, tetapi juga ditemukan 3 versi bahasa daerah lain, yaitu Aceh, Bugis, dan Makasar (Mulyadi, 1983). Jumlah yang tidak sedikit ini memperlihatkan adanya peran yang penting dari naskah $H I$ tersebut.

Sampai saat ini, HI telah dikaji oleh beberapa ahli. Di antaranya adalah (Winstedt, 1920) dalam artikel yang berjudul The Date of the Hikayat Inderaputera, Sri Wulan Rujiati (Mulyadi, 1983) dalam buku yang berjudul Hikayat Indraputra. A Malay Romance, (Istanti, 2013) dalam jurnal ilmiah yang berjudul Unsur Kepahlawanan Hikayat Indraputra, dan (Ma'rifat, 2019) dalam artikel prosiding yang berjudul Studi Bandingan Dua Cerita dalam Manuskrip Nusantara: Sebuah Kajian Filologi.

HI dapat dikatakan sebagai karya yang sangat populer karena terlihat dari naskah sambutan HI yang banyak dalam sastra Melayu dan non-Melayu sebagaimana uraian di atas. Ini menunjukkan bahwa $H I$ memiliki kandungan nilainilai yang dapat menjadi pedoman hidup manusia secara luas. Salah satunya adalah nilai pendidikan. Nilai pendidikan yang dimaksudkan dalam penelitian ini adalah pengasuhan anak usia dini. Anak usia dini didefinisikan oleh National Association for the Education of Young Children (NAEYC) yaitu asosiasi para pendidik anak yang berpusat di Amerika, sebagai rentang usia anak usia dini berdasarkan perkembangan hasil penelitian di bidang psikologi perkembangan anak yang mengindikasikan bahwa terdapat pola umum yang dapat diprediksi menyangkut perkembangan yang terjadi selama 8 tahun pertama kehidupan anak. NAEYC membagi anak usia dini menjadi 0-3 tahun, 3-5 tahun, dan 6-8 tahun. Menurut definisi ini anak usia dini merupakan kelompok manusia yang berada pada proses pertumbuhan dan perkembangan. Hal ini mengisyaratkan bahwa anak usia dini adalah individu yang unik yang memiliki pola pertumbuhan dan perkembangan fisik, kognitif, sosio-emosional, kreativitas, bahasa dan komunikasi yang khusus sesuai dengan tahapan yang sedang dilalui oleh anak tersebut.

Braginsky dalam penelitiannya terhadap karya-karya sastra Melayu menggariskan adanya tiga lingkaran fungsi, yaitu fungsi keindahan, fungsi kemanfaatan, dan fungsi kesempurnaan jiwa (Abdullah, 1998). Ketiga fungsi ini tidak hanya terdapat pada satu kelompok saja, tetapi bisa juga terdapat pada kelompok lain. Hanya saja, bobot fungsi pada masing-masing kelompok berbeda (Braginsky, 1993). Ketiga lingkaran fungsi tersebut memenuhi tugasnya dengan pertolongan "struktur genre". Istilah-istilah struktur genre berbeda-beda berdasarkan sifatnya masing-masing. Terdapat dua struktur genre dalam hubungannya dengan 
lingkaran fungsi. Pertama, istilah sejarah dan nasihat yang merujuk pada sifat karangan yang hanya memenuhi lingkup faedah atau manfaat saja. Kedua, istilahistilah hikayat, syair, dan kitab. Hikayat dan syair memenuhi ketiga lingkup fungsional, sedangkan kitab memenuhi lingkup faedah dan lingkup kesempurnaan jiwa (Braginsky, 1998).

Salah satu keunggulan terpenting suatu karya sastra adalah sifat indahnya. Keindahan sendiri dipandang sebagai sesuatu yang luar biasa yang menarik perhatian dan membangkitkan orang untuk melihat atau mendengarnya. Keindahan ini menimbulkan perasaan kagum dalam jiwa manusia, jika keindahan ini dihayati secara teratur, dapat menjadi penghibur hati atau penglipur lara. Fungsi keindahan ini tidak hanya tertumpu pada cara penyampaiannya, tetapi berkaitan juga pada struktur pembangun cerita dan sistem penerapannya (Braginsky, 1998).

Disamping keindahan yang dapat dipandang sebagai "keindahan luar" tersebut, ada sifat lain dari karya sastra yang dipandang lebih penting, yaitu faedah atau manfaat. Faedah atau manfaat ini dipandang sebagai "keindahan dalam" karya sastra (Braginsky, 1998). Faedah ini bertujuan untuk membentuk manusia menjadi makhluk sosial yang memiliki budaya berperasaan, berpikir, dan tingkah laku yang halus (adab), atau menjadi pribadi yang bercenderung pada kognisi ilmiah secara sistematis (ilmu) terhadap berbagai aspek alam semesta (Braginsky, 1998).

Fungsi ketiga dan yang tertinggi dari sistem sastra Melayu adalah fungsi kesempurnaan jiwa yang mencakup hal-hal yang berhubungan dengan agama dan karya-karya mistik. Karya-karya yang termasuk dalam fungsi ini tidak seperti yang termasuk dalam dua fungsi di atas memenuhi fungsi membuka hati nurani sehingga setelah membacanya, pembaca seperti mendapat berkah kemampuan berkontemplasi pada tingkat yang lebih tinggi. Karya yang termasuk kesempurnaan jiwa meliputi kelompok cerita tentang orang-orang suci, termasuk tentang para nabi, sahabat-sahabat nabi, musuh-musuh nabi, dan kelompok sastra kitab (Braginsky, 1993).

Pengertian fungsi yang sesuai dengan tujuan dari penelitian ini adalah fungsi dalam pengertian kegunaan, suatu pendekatan karya sastra berorientasi pragmatik. Oleh karenanya, konsep teori fungsi yang dipergunakan dalam studi ini adalah teori lingkaran fungsi dari Braginsky pada fungsi faedah atau manfaat. Ditilik dari karakteristik yang dimiliki $H I$, nuansa pengasuhan anak usia dini cukup menonjol dalam hikayat ini, terutama pengasuhan Maharaja Bikrama Bispa terhadap anaknya, Indraputra.

Pengasuhan atau parenting dapat diartikan sebagai segala hal yang mencakup apa seharusnya dilakukan oleh orang tua (baca: pengasuh) dalam menjalankan tugas-tugas dan tanggung jawab terhadap perkembangan anak. Tugas orang tua ini tidak sekadar pemenuhan kebutuhan fisik, tetapi juga memberikan yang terbaik bagi kebutuhan anak, memenuhi kebutuhan emosi dan psikologis anak, dan menyediakan kesempatan untuk menempuh pendidikan yang terbaik (Z. Hidayati, 2010). Pola pengasuhan anak dalam rujukan lain diuraikan sebaga sikap dan perilaku ibu atau pengasuh lain dalam hal kedekatannya dengan anak memberikan makanan, merawat kebersihan, semuanya itu berhubungan dengan keadaan ibu dalam hal kesehatan (fisik mental) status gizi, pendidikan umum keluarga dan masyarakat untuk pengetahuan tentang pengasuhan anak yang baik, peran dalam keluarga atau di masyarakat, sifat pekerjaan sehari-hari, adat kebiasaan keluarga dan masyarakat membagi kasih sayang dan sebagainya seibu atau pengasuhan 
anak. Adapun faktor-faktor yang mempengaruhi pola asuh antara lain: pendidikan orangtua (Suhardjo, 1996), pengetahuan dan aktivitas orangtua (Sobur, 1991), serta status sosial ekonomi.

\section{METODOLOGI}

Metode yang digunakan dalam penelitian ini adalah filologi dengan menggunakan pendekatan analisis lingkaran fungsi Braginsky. Objek material dalam penelitian ini adalah naskah HI yang ditemukan di the Koninklijk Instituut voor Taal-, Land- en Volkenkunde di Leiden dan telah disunting oleh Sri Wulan Rujiati (Mulyadi, 1983), sedangkan objek formalnya adalah nilai guna teks HI bagi pembacanya, yaitu yang berkaitan dengan pengasuhan anak usia dini. Penentuan data yang digunakan adalah purposive sampling, yaitu pemilihan data tertulis yang tergolong dalam pengasuhan anak usia dini dilihat dari isi teks yang mengandung indikator pengasuhan anak.

Instrumen penelitian yang digunakan adalah manusia, yaitu peneliti sendiri dengan menggunakan beberapa indikator sebagai pedoman operasional. Indikatorindikator itu adalah apa yang dituju oleh pengarang dan signifikansi teks-teks tertentu dalam keseluruhannya. Penelitian ini menggunakan teknik dokumentasi sebagai teknik pengumpulan data, dengan memperhatikan indikator pedoman operasional. Indikator pedoman operasional yang dimaksud adalah perilakuperilaku yang yang ditunjukkan atau ditampilkan orang tua, dalam hal ini Maharaja Bikrama Bispa dalam merawat anaknya yaitu Indraputra. Indikator tersebut meliputi kegiatan asuh, asih, dan asah. Asuh adalah aspek pengasuhan fisik yang meliputi memberi asupan makanan, minuman, tempat tinggal, pakaian, dan lainlain. Asih adalah pemenuhan kasih sayang yang dapat ditunjukkan dengan berbagai bentuk perilaku seperti menimang, membelikan mainan, mengajak bermain, dan lain-lain. Asah adalah kegiatan memberikan stimulasi untuk mengembangkan atau mengasah kesemua aspek perkembangan anak meliputi kognitif, bahasa, sosial emosional, fisik motorik, seni, serta nilai agama dan moral.

Dengan panduan ketiga aspek pengasuhan tersebut di atas, peneliti menyunting dan mereduksi teks, memilih teks-teks yang bermuatan pengasuhan anak. Proses ini dinamakan dengan proses reduksi data yang ada dalam tahapan analisis data. Reduksi data merupakan bagian dari analisis. Reduksi data merupakan suatu bentuk analisis yang menajamkan, menggolongkan, mengarahkan, membuang yang tidak perlu, dan mengorganisasi data dengan cara sedemikian rupa hingga kesimpulan-kesimpulan finalnya dapat ditarik dan diverifikasi. Dalam hal ini peneliti menajamkan, menggolongkan, mengarahkan, dan mengorganisasi data-data yang menunjukkan perilaku pengasuhan anak.

\section{HASIL DAN PEMBAHASAN}

$H I$ adalah cerita tentang Indraputra. Indraputra merupakan tokoh sentral atau tokoh utama yang menjadi pendorong semua peristiwa. Sebagai tokoh utama, tokoh Indraputra merupakan tokoh yang paling banyak diceritakan dan selalu berhubungan dengan tokoh-tokoh yang lain. Tentunya, tokoh ini juga merupakan tokoh yang sering bertemu dengan masalah dan konflik. HI dimulai dengan menceritakan asal-usul tokoh utama, Indraputra, yang merupakan keturunan seorang raja yang bernama Maharaja Bikrama Bispa. 
"Bermula sekali peristiwa ada seorang raja di Negeri Samantapuri dan nama raja itu Maharaja Bikrama Bispa dan akan raja itu terlalu besar kerajaannya. Syahdan, beberapa raja-raja takluk kepadanya memberi upeti pada genap tahun, dan empat puluh raja-raja yang memakai kulah yang keemasan dengan alat senjata hadir di bawah istana raja itu. Demikian peri kebesaran raja itu." (Mulyadi, 1983).

Kutipan di atas memperlihatkan Negeri Samantapuri sebagai kerajaan besar yang menguasai wilayah yang luas karena membawahi beberapa kerajaan. Setiap tahunnya, kerajaan-kerajaan yang pernah ditaklukkan itu memberikan upeti sebagai tanda ketundukan dan kesetiaan kepada Negeri Samantapuri. Setidaknya, ada empat puluh kerajaan yang menjadi kerajaan bawahan Negeri Samantapuri. Ini digambarkan dengan kehadiran empat puluh raja dengan memakai mahkota kebesaran kerajaannya masing-masing di Negeri Samantapuri. Kehadiran mereka di Negeri Samantapuri ini dipahami adanya pertemuan para raja-raja taklukan dengan Maharaja Bikrama Bispa di setiap tahunnya seraya menyerahkan upeti.

Selain hal di atas, penyematan gelar "maharaja" menunjukkan tingkatan derajat penguasa Negeri Samantapuri atas penguasa kerajaan-kerajaan lainnya. Maharaja adalah gelar yang berada di atas raja-raja karena digunakan untuk penguasa monarki yang memiliki wilayah sangat luas dengan beberapa penguasa bawahan berada dalam kekuasaannya. Gelar ini berasal dari bahasa Hindi dan Sanskerta kuno (maharaja). Dalam bahasa Sanskerta, maharaja berarti raja agung. Pada perkembangannya, walaupun pengaruh Islam sudah cukup kental di Nusantara, istilah ini masih tetap digunakan dengan makna yang sama.

Maharaja Bikrama Bispa menyadari bahwa anaknya Indraputra adalah putra mahkota, pewaris kerajaan Negeri Samantapuri. Masa depan kerajaan berada di pundak anaknya. Untuk itu, Maharaja Bikrama Bispa sangat menaruh perhatian terhadap anaknya itu. Dalam HI, dinyatakan bahwa Indraputra dalam pengasuhan Maharaja Bikrama Bispa hanya sampai usia tujuh tahun sebagaimana pendapat ahli nujum kepada Maharaja Bikrama Bispa (Mulyadi, 1983). Selanjutnya, Indraputra diculik oleh burung Merak Emas yang kemudian dijatuhkan di kebun Nenek Kebayan (Mulyadi, 1983).

Indraputra dari lahirnya hingga usia tujuh tahun sebagaimana keterangan di atas tergolong anak usia dini. Anak usia dini (early child) yang dimaksudkan di sini adalah usia dari kelahiran hingga enam tahun atau hingga delapan tahun. Pada usia ini, seluruh potensi anak mengalami masa tumbuh kembang secara cepat dan perkembangannya sangat menentukan kualitas anak di masa yang akan datang. Oleh karena itu, usia di tahun-tahun pertama ini dikenal dengan usia emas (golden age).

Dengan memperhatikan pedoman operasional, pengasuhan anak usia dini yang ditemukan merupakan hasil pemahaman dalam pembacaan HI dengan menelaah ide-ide dasar atau tema sentral yang ditekankan dalam cerita seraya menghubungkannya dengan literatur-literatur lain untuk menarik titik temu antara pengasuhan anak usia dini dalam $H I$ dan pemikiran pengasuhan anak usia dini dalam pelbagai referensi. 
Tabel 1. Pengasuhan Anak Usia Dini dalam Hikayat Indraputra

\begin{tabular}{|c|c|c|c|c|}
\hline $\begin{array}{l}\text { Cerita } \\
\text { ke- }\end{array}$ & Isi Cerita & $\begin{array}{l}\text { Pengasuhan } \\
\text { Anak Usia Dini } \\
\text { dalam HI }\end{array}$ & $\begin{array}{c}\text { Halaman } \\
\text { Suntingan } \\
\text { SRW } \\
\text { Mulyadi }\end{array}$ & $\begin{array}{c}\text { Halaman } \\
\text { Naskah } \\
\quad \text { HI }\end{array}$ \\
\hline 1 & $\begin{array}{l}\text { Kegembiraan Maharaja Bikrama Bispa } \\
\text { karena istrinya, Tuan Putri Jumjum } \\
\text { Ratnadewi, melahirkan anaknya. }\end{array}$ & $\begin{array}{l}\text { Bersukasita atas } \\
\text { kelahiran anak }\end{array}$ & 50 & $4 / 5$ \\
\hline 2 & $\begin{array}{l}\text { Sukacita Raja Syahsian karena istrinya } \\
\text { melahirkan anaknya }\end{array}$ & $\begin{array}{l}\text { Bersukacita atas } \\
\text { kelahiran anak }\end{array}$ & 170 & 136 \\
\hline 3 & $\begin{array}{l}\text { Maharaja Bikram Bispa memberikan nama } \\
\text { Indraputra pada anaknya yang baru lahir }\end{array}$ & $\begin{array}{l}\text { Memberi nama } \\
\text { yang baik pada } \\
\text { anak }\end{array}$ & 50 & 5 \\
\hline 4 & $\begin{array}{l}\text { Raja Syahsian memberikan nama Tuan Putri } \\
\text { Mengindra Sari Bunga pada anaknya yang } \\
\text { baru lahir }\end{array}$ & $\begin{array}{l}\text { Memberi nama } \\
\text { yang baik pada } \\
\text { anaknya }\end{array}$ & 170 & 136 \\
\hline 5 & $\begin{array}{l}\text { Maharaja Bikrama Bispa meminta pendapat } \\
\text { ahli nujum tentang apa yang harus } \\
\text { dilakukannya untuk Indraputra }\end{array}$ & $\begin{array}{l}\text { Memberi } \\
\text { perlindungan } \\
\text { pada anak }\end{array}$ & 50 & 5 \\
\hline 6 & Indraputra mengobati putri Raja Syahsyian. & $\begin{array}{l}\text { Memberi } \\
\text { perlindungan } \\
\text { pada anak }\end{array}$ & $173 / 174$ & $140 / 141$ \\
\hline 7 & $\begin{array}{l}\text { Maharaja Bikrama Bispa mengadakan } \\
\text { jamuan kenegaraan atas kelahiran anaknya }\end{array}$ & $\begin{array}{l}\text { Bersyukur atas } \\
\text { kelahiran anak }\end{array}$ & 50 & 5 \\
\hline 8 & $\begin{array}{l}\text { Maharaja Bikrama Bispa menyantuni fakir } \\
\text { miskin dan memberikan hadiah pada pejabat } \\
\text { istana dan konglomerat di kerajaannya }\end{array}$ & $\begin{array}{l}\text { Bersyukur atas } \\
\text { kelahiran anak }\end{array}$ & 50 & 5 \\
\hline 9 & $\begin{array}{l}\text { Raja Syahsian mengeluarkan emas dan perak } \\
\text { untuk memberi sedekah pada fakir miskin }\end{array}$ & $\begin{array}{l}\text { Bersyukur atas } \\
\text { kelahiran anak }\end{array}$ & 170 & 136 \\
\hline 10 & $\begin{array}{l}\text { Maharaja Bikrama Bispa mendatangkan guru } \\
\text { untuk mengajari Alquran pada Indraputra }\end{array}$ & $\begin{array}{l}\text { Mengenalkan } \\
\text { agama pada } \\
\text { anak }\end{array}$ & 51 & 5 \\
\hline 11 & $\begin{array}{l}\text { Maharaja Bikrama Bispa menerima hadiah } \\
\text { dari tukang kayu dan tukang emas yang } \\
\text { merupakan duta dari kerajaan bawahannya. }\end{array}$ & $\begin{array}{l}\text { Memberikan } \\
\text { stimulasi pada } \\
\text { anak }\end{array}$ & 51 & 6 \\
\hline 12 & $\begin{array}{l}\text { Indraputra diangkat anak oleh Nenek } \\
\text { Kebayan }\end{array}$ & $\begin{array}{l}\text { Menjaga } \\
\text { kebersihan anak }\end{array}$ & 52 & 7 \\
\hline 13 & $\begin{array}{l}\text { Indraputra diperlakukan seperti cucu sendiri } \\
\text { oleh Nenek Kebayan. }\end{array}$ & $\begin{array}{l}\text { Membahagiaka } \\
\mathrm{n} \text { anak }\end{array}$ & 52 & 7 \\
\hline 14 & $\begin{array}{l}\text { Indraputra banyak menerima hadiah dari } \\
\text { orang lain saat ikut serta Nenek Kebayan } \\
\text { untuk berjualan bunga. }\end{array}$ & $\begin{array}{l}\text { Membahagiaka } \\
\mathrm{n} \text { anak }\end{array}$ & 52 & 8 \\
\hline 15 & $\begin{array}{l}\text { Indraputra diangkat anak oleh perdana } \\
\text { menteri kerajaan yang dirajai oleh Raja } \\
\text { Syahsyian. }\end{array}$ & $\begin{array}{l}\text { Membahagiaka } \\
\mathrm{n} \text { anak }\end{array}$ & 53 & $8 / 9$ \\
\hline 16 & $\begin{array}{l}\text { Indraputra menemani anak-anak raja jin } \\
\text { bermain sambil menyantap buah-buahan. }\end{array}$ & $\begin{array}{l}\text { Membahagiaka } \\
\mathrm{n} \text { anak }\end{array}$ & 98 & 59 \\
\hline 17 & $\begin{array}{l}\text { Sejak hilangnya Indraputra, Maharaja } \\
\text { Bikrama Bispa selalu berdoa di masjid agar } \\
\text { dapat bertemu kembali dengan anaknya. }\end{array}$ & $\begin{array}{l}\text { Mendoakan } \\
\text { anak }\end{array}$ & 119 & 168 \\
\hline
\end{tabular}

\section{Bersukacita atas Kelahiran Anak}

Kelahiran seorang anak merupakan kebahagiaan bagi pasangan yang sangat mengharapkan kehadiran seorang anak, apalagi anak itu sudah lama dinantikan. Anak adalah anugerah. Untuk itu, memang sepatutnya kelahiran anak disambut 
dengan sukacita. Ini dialami oleh Maharaja Bikrama Bispa dan istrinya, Tuan Putri Jumjum Ratnadewi. Maharaja Bikrama Bispa adalah seorang raja di Negeri Samantapuri. Kelahiran anak raja tidak hanya dinantikan oleh keluarga kerajaan, tetapi seluruh rakyat ingin mengetahuinya agar turut merasakan kegembiraan. Berita gembira ini harus disebarkan ke penjuru negeri dengan bunyi-bunyian sebagai tanda. Itulah cara yang dilakukan sesuai adat bagi seorang raja yang memperoleh putra.

"Setelah demikian, maka baginda pun terlalu amat sukacita melihat anakanda baginda itu. Maka raja pun menyuruh orang memalu bunyi-bunyian seperti (4) adat segala raja-raja berputra" (Mulyadi, 1983).

Kejadian yang dialami Maharaja Bikrama Bispa juga terjadi pada Raja Syahsyian. Ia pun merasakan kegembiran karena putrinya lahir ke dunia. Sebagaimana adat raja-raja, Raja Syahsyian mengabarkan kelahiran penerusnya ke pelosok negeri dengan bunyi-bunyian (Mulyadi, 1983).

Rasa sukacita Maharaja Bikrama Bispa merupakan pendidikan pertama bagi anak pasca kelahirannya. Sukacita itu adalah wujud rasa ikhlas atas kehadiran sang anak ke dunia. Dengan sikap ikhlas menerima kelahiran anak, baik laki-laki maupun perempuan, orangtua tersebut akan ikhlas pula mendidik anaknya hingga kelak ia dewasa. Sebaliknya, jika orangtua tidak senang terhadap kelahiran anak, sikap tersebut akan berpengaruh secara psikologis terhadap pendidikan anak di masa selanjutnya. Bisa jadi, orangtua tersebut tidak bersikap lemah-lembut, tidak penuh kasih-sayang, mudah marah kepada si anak, tidak bersikap adil, dan sebagainya (Sholeh, 2003). Jadi, orangtua harus ikhlas dalam menerima kelahiran anak dengan cara yang baik, bagaimana pun kondisinya, seperti yang dilakukan Maharaja Bikrama Bispa.

Kebahagiaan karena memiliki seorang anak menjadi motivasi yang kuat bagi orang tua dalam mengasuh anak selanjutnya. Tanpa motivasi yang kuat, orang tua akan mudah lelah dan mungkin banyak mengeluh ketika menghadapi kenyataan bahwa terdapat perubahan yang sangat besar antara sebelum dan sesudah memiliki anak, yang mana perubahan tersebut jika tidak diantisipasi dan segera disikapi dengan penyesuaian diri yang baik, akan menimbulkan masalah yang cukup serius, baik masalah bagi si anak, maupun orang tua. Banyaknya kasus ibu atau ayah yang menyakiti atau melukai, bahkan membunuh buah hatinya karena ketidak mampuan mengendalikan emosi atau mengelola waktu, tenaga dan fikirannya, adalah fakta bahwa bagi beberapa orang tua, kegiatan mengasuh bukanlah kegiatan yang mudah dan sepele. Bahwa gangguan Baby Blues Syndrome adalah gangguan yang banyak dialami oleh ibu yang baru melahirkan anak, yang secara psikologis belum mampu menyesuaikan diri dengan kondisi dirinya yang baru, yakni sebagai seorang ibu. Secara psikologis, ibu yang baru saja melahirkan biasanya akan merasakan gejalagejala psikiatik. Ibu harus dapat menyesuaikan diri dengan perannya yang baru sebagai ibu, baik secara fisik maupun psikis. Sebagian ibu ada yang berhasil menghadapi proses penyesuaian diri tersebut, dan sebagian pula ada yang tidak bisa menyesuaikan diri. Bahkan bagi sebagian ibu yang lain tidak dapat menyesuaikan diri dan mengalami gangguan-gangguan psikologis dengan berbagai macam sindrom atau gejala yang oleh para peneliti disebut dengan postpartum blues (Nirwana, 2011). Postpartum blues ini dikategorikan sebagai sindrom gangguan 
mental yang ringan. Oleh sebab itu, gangguan ini sering tidak dipedulikan bahkan sering dianggap sebagai efek samping dari keletihan, sehingga tidak terdiagnosis dan tidak tertangani sebagaimana harusnya. Data dari penelitian di seluruh dunia secara tegas menunjukkan bahwa sekitar 50-75\% wanita mengalami postpartum blues (Mansur, 2009).

Kesiapan orang tua untuk menjalankan perannya dalam pengasuhan anak ditunjukkan dengan kebahagiaan akan lahirnya anak, kesediaan untuk beradaptasi dan mempelajari perannya yang baru, kesediaannya untuk membagi waktu dan kegiatannya, serta secara umum kesiapan dalam asuh, asih dan asah. Yaitu kesiapan memberikan pengasuhan biologis, pengasuhan psikologis afektif, serta pengasuhan stimulatif yang merujuk pada pengembangan seluruh aspek perkembangan seorang anak. Dalam HI, rasa sukacita yang ditunjukkan oleh keluarga kerajaan adalah indikator kuat yang menunjukkan kesiapan keluarga untuk menerima dan menjalankan peran pengasuhan anak, yaitu Indraputra.

\section{Memberi Nama yang Baik pada Anak}

Setelah mengetahui laki-laki atau perempuan, hal kedua yang ingin diketahui oleh seseorang ketika melihat bayi yang baru lahir adalah nama bayi tersebut. Nama tidak sekadar identitas atau simbol seseorang karena nama mengandung doa dan harapan tertentu. Harapannya adalah suatu hal yang sesuai dengan kandungan makna dari nama tersebut. Hal ini juga dilakukan oleh Maharaja Bikrama Bispa dengan memberi nama Indraputra pada anaknya yang baru lahir. "Demikianlah maka dinamai akan anakanda itu Indraputra" (Mulyadi, 1983).

Indra dalam ajaran agama Hindu adalah raja kahyangan. Dia adalah dewa yang memimpin delapan dewa yang menguasai aspek-aspek alam. Dia juga diberi gelar dewa petir, dewa hujan, dewa perang, raja surga, pemimpin para dewa, dan sebutan lain sesuai dengan karakter yang dimilikinya (wikipedia.org/wiki/Indra). Jadi, tidak berlebihan jika Maharaja Bikrama Bispa memberi nama anaknya dengan nama Indraputra untuk mengharap kehebatan dari Dewa Indra. Hal ini sama halnya dengan umat Islam yang memberi nama anaknya dengan Abdullah atau Abdurrahman.

Ini tidak mengherankan. HI diklasifikasikan sebagai hikayat zaman peralihan dari Hindu ke Islam (Fang, 1982). Hal ini terlihat dari ciri-ciri sastra masa peralihan yang ada dalam hikayat ini, seperti nama-nama tokoh yang masih sangat kental bernuansa Hindu, walaupun HI ditulis dengan huruf Jawi (Arab-Melayu) dan rona keislamannya juga terlihat jelas, seperti penyebutan nama Allah di semua naskah $H I$ (Mulyadi, 1983).

Pemberian nama yang baik ini juga dilakukan oleh Raja Syahsian. Ia memberikan nama pada putrinya dengan Tuan Putri Mengindra Sari Bunga (Mulyadi, 1983). Suatu kelaziman bahwa kata 'sari' dan 'bunga' untuk nama feminim. Kedua kata itu masih dijumpai untuk nama seorang anak hingga sekarang. Dengan memerhatikan kebaikan dan harapan bagi anak, pemberian nama anak perlu adanya pertimbangan-pertimbangan yang mendalam dari orangtua, baik makna maupun panggilannya. Nama dapat memengaruhi pergaulan anak. Nama yang baik akan menumbuhkan rasa percaya diri pada anak. Sebaliknya, nama yang buruk akan menjadikan anak kurang percaya diri. Selain sebagai identitas diri, anak akan membawa nama itu di setiap keadaannya. Nama itu akan selalu melekat 
hingga akhir hidupnya, bahkan setelah kematiannya pun, nama itu akan tetap dikenang.

Dalam banyak budaya, pemberian nama untuk seorang bayi bukanlah sesuatu yang dapat dianggap sepele. Banyak sekali pertimbangan yang digunakan oleh pasangan orang tua untuk memberikan sebuah nama bagi anaknya. Mulai dari bahasa asal yang digunakan sebagai nama, arti kata yang digunakan sebagai nama, popularitas nama, nilai kemodernan sebuah nama, gaya hidup, keunikan nama, sumber ide pemberian nama (misalnya mengambil nama dari nama tokoh idola), bahkan tak jarang pasangan orang tua yang memberikan nama kepada anaknya yang menyiratkan sebuah peristiwa yang dikenang oleh orang tuanya. Dapat dikatakan nama adalah realisasi ide orang tua yang lahirnya nama tersebut dapat menyiratkan kondisi psikologis, keyakinan, motivasi, rasa syukur, harapan, serta do'a yang disematkan oleh orang tua melalui nama yang diberikan kepada anaknya. Dalam Islam pun pemberian nama untuk bayi merupakan tuntunan Rasul. Dari Abu Hurairah ra, Nabi saw bersabda, "Sesungguhnya kewajiban orang tua dalam memenuhi hak anak itu ada tiga, yakni: pertama, memberi nama yang baik ketika lahir. Kedua, mendidiknya dengan tuntunan al-Qur'an, dan kewajiban ketiga adalah mengawinkan ketika menginjak dewasa." Rasulullah saw memberi perhatian yang sangat besar terhadap masalah nama. Kapan saja beliau menjumpai nama yang tidak patut atau tak berarti maknanya beliau mengubahnya dan memilih beberapa nama yang pantas. Beliau mengubah macam-macam nama laki-laki dan perempuan. Seperti dalam hadits yang disampaikan oleh Aisyah ra, bahwa Rasulullah saw biasa merubah nama-nama yang tidak baik.

Pemberian nama menjadi sangat penting dan tak dapat dikatakan sepele ketika dalam masyarakat modern seperti saat ini banyak ditemukan kejadian perundungan (bullying) terhadap anak yang salah satunya berupa kekerasan verbal. Kekerasan verbal dapat diterima oleh anak dari lingkungan pergaulan yang tak sehat, misalnya ketika anak mendapatkan ejekan karena namanya yang unik atau yang dapat diidentikkan dengan kondisi tertentu yang dapat mengundang ejekan atau hinaan. Kekerasan verbal juga dapat berupa panggilan yang tak disukai oleh anak yang dikaitkan dengan namanya, atau julukan yang mirip atau cenderung dapat disalahgunakan Karen memiliki kemiripan dengan namanya. Perundungan bukanlah hal yang remeh terjadi dalam masyarakat modern. Kondisi psikologis serta kecenderungan kepribadian seorang anak dapat mempengaruhi bagaimana ia akan bersikap menghadapi hal tersebut. Tak jarang kasus perundungan menyebabkan anak mogok sekolah, frustasi, turun kepercayaan dirinya, sikap minder atau inferior, bahkan bunuh diri karena tekanan yang bertubi-tubi yang tak bisa dihadapinya.

Mencegah tentu lebih baik, dan lebih mudah, daripada mengobati. Demikian juga dalam mencegah terjadinya perundungan terhadap anak, khususnya yang berbentuk kekerasan verbal berupa panggilan ejekan atau julukan yang tak disukai oleh anak. Dalam HI, nama Indraputra adalah nama yang dipilih oleh seorang ayah yang yaitu Maharaja Bikrama Bispa yang mana nama tersebut diambil dari nama pemimpin para dewa. Demikian juga nama putri Raja Syahsian yaitu Tuan Putri Mengindra Sari Bunga, yang mana nama tersebut diambil dari sifat tanaman bunga yang cantik jelita. Hal tersebut menyiratkan doa serta harapan orang tua akan tumbuh kembang anaknya hingga dewasa nanti agar tetap indah dan terberkati seperti namanya. 


\section{Memberi Perlindungan pada Anak}

Sebagai seorang ayah, Maharaja Bikrama Bispa berusaha untuk menjaga anaknya sebaik-sebaiknya. Untuk usaha ini, Maharaja Bikrama Bispa mengundang ahli nujum untuk dimintakan pendapat mereka tentang Indraputra, anaknya, dan masa depannya.

“Maka Maharaja Bikrama Bispa menyuruh memanggil segala ahlunnujum dan sastrawan. Maka setelah datang segala ahlunnujum, maka Maharaja Bikrama Bispa memberi titah pada segala ahlunnujum, "Betapa peri kebesaran anakku ini?" (Mulyadi, 1983).

Sebagai orang yang mampu melihat masa depan, ahli nujum memberitahukan kepada Maharaja Bikrama Bispa bahwa kebersamaannya dengan Indraputra hanya sampai usia Indraputra tujuh tahun. Ia akan berpisah dengan anaknya. Ahli nujum memberikan nasihat kepada Maharaja Bikrama Bispa tentang apa yang harus ia dilakukan dan apa yang tidak boleh dilakukan terhadap Indraputra untuk menghindari berpisahnya ia terhadap anaknya.

“... dan jangan paduka anakanda itu tuanku beri bermain binatang karena sebab paduka anakanda bermain binatang itu jadi beroleh bencana, bercerai dengan duli tuanku" (Mulyadi, 1983).

Dari kutipan itu, Maharaja Bikrama Bispa disarankan oleh ahli nujum agar Indraputra tidak bermain dengan hewan karena akan menjadi sumber penyebab ia akan berpisah dengan Indraputra. Hanya saja, ahli nujum tidak memberitahukan hewan apa yang dimaksud.

Maharaja Bikrama Bispa baru menyadari hewan apa yang dimaksud oleh ahli nujum itu saat kedatangan dua utusan dari kerajaan bawahan untuk menyerahkan upeti. Dua utusan itu adalah tukang kayu dan tukang emas. Selain upeti, tukang kayu menghadiahi Maharaja Bikrama Bispa dengan ukiran ikan kayu dan tukang emas memberikannya ukiran burung Merak Emas. Kedua ukiran itu dengan kemahiran mereka mampu hidup sebagaimana aslinya. Tanpa disadari, burung Merak Emas inilah yang menculik Indraputra yang membawanya terbang hingga dijatuhkan di negeri yang jauh dari Negeri Samantapuri, tepatnya dijatuhkan di kebun Nenek Kebayan (Mulyadi, 1983).

Sejatinya, Maharaja Bikrama Bispa telah melaksanakan pengawasan dan penjagaan terhadap anaknya. Ia selalu ingat dengan pesan ahli nujum sebelumnya. Di mana pun dan dalam stuasi apapun, Indraputra selalu berada di dekatnya agar senantiasa dalam pengawasannya, bahkan dalam pertemuan resmi kerajaan pun Indraputra selalu di dekatnya.

“Maka Maharaja Bikrama Bispa pun mangkin sangat kasihnya akan anakanda baginda Indraputra, seketika pun tiada bercerai, 5 karena baginda sangat memeliharakan pesan alunnujum; dan jika baginda diadap segala raja-raja dan menteri hulubalang pun anakanda itu tiada bercerai dengan baginda" (Mulyadi, 1983).

Dengan mengikuti nasihat ahli nujum, Maharaja Bikrama Bispa menjauhkan Indraputra dari hewan. Hanya saja, ia memahami perkataan ahli nujum dengan hewan sebagaimana hewan pada umumnya. Ia tidak menyadari bahwa hewan yang 
akan membahayakan keselamatan Indraputra adalah hewan ajaib pemberian tukang emas.
“Setelah Maharaja Bikrama Bispa melihat anakanda baginda hilang itu maka baginda pun murca seketika. Setelah baginda sadar akan dirinya maka baginda menangis terlalu sangat dengan segala isi istana gempar menangis. Maka segala isi negeri pun semuanya dukacita mendengar Indraputra hilang itu" (Mulyadi, 1983).

Terlihat jelas bahwa Maharaja Bikrama Bispa menyesali kecerobohannya dalam menjaga Indraputra. Menyadari anaknya hilang, Maharaja Bikrama Bispa langsung pingsan seketika itu. Setelah sadar, ia menangis atas kelalaiannya yang disambut tangis oleh seluruh penghuni istana. Negeri Samantapuri pun berdukacita atas hilangnya sang putra mahkota, Indraputra.

Kisah Maharaja Bikrama yang kehilangan anaknya ini mengisyratkan bahwa perlindungan bagi anak dari orang dewasa, terutama dari kedua orang tua anak, sangat diperlukan. Hal ini bertujuan untuk menjamin pertumbuhan dan perkembangan anak secara wajar, baik jaminan keselamatan fisik, mental, sosial, maupun spiritual. Dalam Undang-Undang Nomor 23 Tahun 2002 tentang Perlindungan Anak Pasal 1 Ayat 2, dinyatakan bahwa perlindungan anak adalah segala kegiatan untuk menjamin dan melindungi anak dan hak-haknya agar dapat hidup, tumbuh, berkembang, dan berpartisipasi, secara optimal sesuai dengan harkat martabat kemanusiaan, serta mendapat perlindungan dari kekerasan tanpa diskriminasi.

Saat ini, pelbagai macam dan bentuk ancaman selalu menyertai anak dalam kehidupannya. Di antaranya adalah penculikan anak; kekerasan pada anak (Purnama, 2016), baik fisik maupun mental; perdagangan anak (Fadilla, 2018); perlantaran anak; eksploitasi secara ekonomi atau seksual; gawai (Purnama, 2018); penyalahgunaan narkotika, alkohol, psikotropika, dan zat adiktif lainnya. Banyaknya jenis ancaman ini menggambarkan tingkat keseriusan dari kondisi tersebut dan dampaknya terhadap masa depan anak. Kewaspadaan orang tua selalu ditingkatkan. Kesadaran orang tua dituntut untuk selalu memberikan perlindungan bagi anak karena melindungi anak merupakan salah satu tugas utama setiap orang tua. Selain hal tersebut, menjaga kesehatan anak juga termasuk salah satu dari pemberian perlindungan pada anak. Hal ini terlihat dari upaya Raja Syahsyian agar putrinya sembuh dari penyakit yang mengidapnya. Kekhawatiran terhadap kondisi anaknya akhirnya sirna karena Indraputra berhasil mengobati putri Raja Syahsian tersebut (Mulyadi, 1983).

Dalam teori Bioekologi yang dicetuskan oleh Urie Bronfenbrenner, tumbuh kembang individu, dalam hal ini seorang anak, dipengaruhi oleh empat lapis cincin lingkungan yang masing-masing lapis memberikan dampak atau pengaruhnya terhadap tumbuh kembang seorang anak. Secara umum, teori bioekologi menyebutkan bahwa perkembangan manusia sepanjang hayat dipengaruhi oleh empat lingkungan dimana ia hidup, yang mana keempat lingkungan tersebut disebut dengan kronosistem (chronosystem) (Berns, 2012). Keempat lingkungan dalam kronosistem tersebut adalah: mikrosistem (microsystem), mesosistem (mesosystem), eksosistem (exosystem), dan makrosistem (macrosystem). Mikrosistem mencakup: keluarga, sekolah, tempat penitipan anak, tetangga dan lingkungan tempat tinggal, media massa yang beredar di sekitar, serta teman sebaya atau teman bermain sehari- 
hari. Mesosistem mencakup: hubungan keluarga dengan tetangga sekitar, kebiasaan teman bermain dalam memilih jenis tontonan televisi di media massa, nilai- nilai yang dikembangkan di sekolah atau penitipan anak, dll. Mesosistem ini merupakan hubungan antar unsur yang ada dalam mikrosistem. Eksosistem mencakup: pekerjaan orangtua, kebijakan sekolah yang berasal dari pemerintah, kondisi perekonomian kota, dll. Eksosistem tidak berpengaruh secara langsung kepada anak akan tetapi dapat dirasakan dampaknya dalam perkembangan anak. Makrosistem mencakup: kondisi negara, agama, perkembangan teknologi, ideologi politik, budaya bangsa, dll. yang lebih luas cakupannya.

Keluarga atau orang tua yang berada pada lingkar pertama dalam bioekologi kehidupan anak, memegang peran yang sangat penting dalam tumbuh-kembang dan sosialisasinya. Rupanya hal tersebut disadari penuh oleh Maharaja Bikrama Bispa sehingga mengupayakan perlindungan penuh terhadap anaknya dengan berbagai upaya. Menyadari bahwa lingkungan dapat menghadirkan bahaya yang mengancam, membuat Maharaja Bikrama Bispa mengantisipasinya dengan meminta pendapat kepada ahli nujum tentang keselamatan anaknya. Saran-saran yang diberikan oleh ahli nujum kepada Maharaja Bikrama Bispa sesungguhnya adalah saran-saran mengenai pola asuh yang tepat untuk putra sang raja demi keselamatannya. Demikian pula yang harus dilakukan oleh para orang tua di zaman modern, bahwa memaksimalkan peran dan fungsi keluarga inti adalah sesuatu yang sangat penting, sehingga tumbuh kembang anak dapat terlindung dan terjamin. Dalam ilmu pengasuhan anak dikenal beberapa gaya atau tipe pengasuhan, yang mana kesemua tipe memiliki kelebihan dan kelemahan apabila diterapkan dalam pengasuhan anak (L. Hidayati, 2016). Secara umum, pengasuhan anak membutuhkan kebijaksanaan tentang apa yang boleh dan apa yang tidak boleh dilakukan kepada anak, aturan-aturan yang disepakati bersama dengan anak, dapat menjadi langkah prefentif orang tua guna mengantisipasi bahaya yang datang dari lingkungan pergaulan anak.

\section{Bersyukur atas Kelahiran Anak}

Kelahiran anak patut disyukuri oleh orang tuanya. Syukur bisa diwujudkan dengan pelbagai cara, yaitu hati, lisan, dan fisik. Secara hati, syukur terlihat dari rasa senang dan menerima apa saja yang ada. Hal ini tergambar dari rasa sukacita Maharaja Bikrama Bispa pada penjelasan terdahulu. Secara lisan, syukur terlihat dari ucapannnya yang baik-baik. Secara fisik, syukur ini diwujudkan dengan melibatkan orang lain, seperti berbagi rezeki.

Wujud rasa syukur secara fisik tentu tidak sebatas ucapan saja, tetapi harus diwujudkan dalam tindakan nyata. Salah satu bentuk implementasi syukur adalah bersedekah atau berbagi rezeki kepada orang lain. Sedekah yang dimaksudkan di sini adalah suatu pemberian yang diberikan oleh seorang kepada orang lain secara spontan dan sukarela tanpa dibatasi oleh waktu dan jumlah tertentu. Sedekah juga berarti suatu pemberian yang diberikan oleh seseorang sebagai kebajikan yang mengharap dan pahala semata (El-Firdausy, 2009).

Sebagai wujud rasa syukur atas kelahiran anaknya, Maharaja Bikrama Bispa beramal dengan berbagi rezeki kepada fakir dan miskin dan memberikan hadiah kepada raja-raja kerajaan bawahannya, menteri, dan pejabat istana. 
“Setelah Maharaja Bikrama Bispa mendengar sembah segala ahlunnujum itu demikian, maka Maharaja Bikrama Bispa memberi anugerah akan segala ahlunnujum dan sastrawan itu, dan memberi anugerah akan segala fakir dan miskin, dan memberi persalin akan segala raja-raja dan menteri dan hulubalang sekalian dan orang kayakaya" (Mulyadi, 1983).

Sebagaimana Maharaja Bikrama Bispa, Raja Syahsyian pun memberikan sedekah pada fakir miskin berupa emas dan perak sebagai wujud syukurnya atas kelahiran anak (Mulyadi, 1983). Dalam agama Islam, rasa syukur atas kelahiran anak itu juga diwujudkan dengan pelaksanaan akikah. Akikah adalah menyembelih hewan kurban untuk kelahiran bayi laki-laki atau perempuan ketika berusia tujuh hari atau usia empat belas hari atau usia dua puluh satu hari yang juga dilakukan pencukuran rambut dan pemberian nama yang baik (Rahman, 2010). Menurut mayoritas ulama dalam (A.K., 2000) akikah adalah menyembelih hewan pada hari ketujuh dari hari lahirnya seorang anak, baik laki-laki maupun perempuan.

Akikah ini pada intinya penyembelihan hewan yang kemudian mengundang sanak keluarga dan tetangga untuk menyantap hewan sembelihan akikah tersebut secara bersama-sama. Perilaku Mahajara Bikrama Bispa yang diuraikan di atas bisa saja dimaknai sebagai akikah. Hal ini terlihat jelas dari kutipan berikut:

"Maka baginda menyuruh memalu bunyi-bunyian, makan minum empat puluh hari empat puluh malam, bersuka-sukaan dengan segala raja-raja dan menteri hulubalang dan orang kaya-kaya sekalian dengan segala bala tentara kecil besar"(Mulyadi, 1983).

Dalam kutipan itu, Maharaja mengadakan pesta besar di istana dengan santapan makan minum selama empat puluh hari empat puluh malam. Undangannya mencakup semua lapisan masyarakat dari rakyat jelata hingga pejabat tinggi; dari yang miskin sampai orang yang kaya raya; dari pegawai rendahan hingga pegawai tinggi. Semuanya tidak dibedakan satu dengan yang lainnya. Mereka larut dalam kegembiraan karena lahirnya putra mahkota di dunia.

Pelaksanaan akikah dalam Islam lazimnya bersamaan dengan pemberian nama dan pencukuran rambut bayi. Pemberian nama bersamaan dengan pelaksanaan akikah ini dapat dimaknai sebagai sosialisasi nama anak pada khalayak sekaligus permohonan doa dari khalayak agar nama itu menjadi yang nama terbaik dan membawa kemanfaatan bagi anak. Pencukuran rambut bayi adalah mencukur semua rambut bayi yang dibawa dari kandungan. Rambut hasil cukuran ini ditimbang dan nilainya diwujudkan emas atau perak yang kemudian disedekahkan kepada fakir miskin.

Sedekah secara umum dimaknai sebagai pemberian sesuatu kepada fakir miskin atau orang yang berhak menerima, orang yang membutuhkan. Manfaat sedekah dalam konteks ini bisa dipandang dari dimensi spiritual dan bisa dengan dimensi sosial, bahkan ada juga dari dimensi kesehatan, kesehatan fisik dan kesehatan psikis. Dalam konteks kelahiran anak, dimensi yang paling tepat itu adalah dimensi spiritual dan sosial. Secara spiritual, ada unsur ibadah dari pelaku dan unsur keberkahan yang bertujuan demi kebaikan anak. Secara sosial, ada unsur kasih sayang antara pemberi dan penerima. Kasih sayang ini berimbas juga pada anak agar orang-orang yang di sekitarnya mau menerima kehadiran anak di tengahtengah mereka dengan penuh kekeluargaan, baik masa sekarang maupun masa kehidupan anak berikutnya. 
Jika pemberian diberikan kepada orang yang tidak berhak atau orang tidak membutuhkan, sebagaimana Maharaja Bikrama Bispa memberikan pelbagai anugerah pada para pejabat dan orang-orang kaya, hal itu bukan dinamai sedekah, tetapi hadiah. Fungsi hadiah ini hampir sama dengan faedah sedekah dalam dimensi sosial, yaitu mempererat rasa kasih sayang, tetapi dari kalangan ekonomi atas. Hal ini dilakukan agar golongan atas bisa menerima kehadiran anak di tengah-tengah mereka

Jika dikaji lebih mendalam, rasa syukur atas kelahiran anak merupakan wujud dari kesediaan menerima anak apa adanya, meliputi kelebihan dan kekurangan yang ada pada anak. Kesediaan untuk menerima segala kekurangan dan kelebihan anak secara proporsional akan menjadi landasan bagi segala upaya pengasuhan anak sampai mereka tumbuh dewasa. Penerimaan penuh atas segala kekurangan dan kelebihan yang ada pada anak akan menjadi peredam ambisi maupun tuntutan-tuntutan orang tau yang terkadang tak realistis terhadap anaknya. Memilihkan berbagai macam pakaian, tayangan televisi, hobi, bidang les, jurusan sekolah atau kuliah, kesemuanya rentan mengandung ambisi pribadi orang tua alihalih memilihkan yang terbaik untuk anak, yang mana jika hal itu dicerabut akarnya akan tampak adanya rasa kurang bersyukur terhadap kondisi atau pencapaian anaknya.

Dalam berbagai warna tipe pengasuhan anak, dikenal juga istilah push parenting. Yaitu model pengasuhan yang serba menekan dan menuntut diri anak. Push parenting merupakan salah satu jenis pola asuh yang termasuk ke dalam kategori authoritarian parenting. Selama ini kita mengenal ada empat jenis pola asuh sebagaimana yang dijelaskan oleh Jack dan Judith Balswick, yang mengatakan bahwa berdasarkan pendekatan socioemotional dikenal empat gaya pengasuhan anak, yaitu (1) neglectful parenting, gaya pengasuhan yang lemah dalam dukungan maupun pengawasan; (2) permissive parenting, gaya pengasuhan yang lemah dalam pengawasan tetapi kuat dalam dukungan; (3) authoritarian parenting, gaya pengasuhan yang lemah dalam dukungan, tetapi kuat dalam pengawasan; (4) authoritative parenting, gaya pengasuhan yang mengkombinasikan kualitas terbaik dari permissive dan authoritarian style (Balswick \& Balswick, 2014).

Gaya pengasuhan push parenting orangtua dapat mematikan bakat atau kreativitas anak, dan bahkan membuat anak kehilangan semangat belajarnya. Gaya pengasuhan push parenting yaitu gaya pengasuhan yang terlalu menuntut kepada anak. Elisabeth Guthrie dan Kathy Matthews (L. Hidayati, 2016) menjelaskan beberapa ciri perilaku yang menjadi tanda dari push parenting yaitu: pertama, mengatur nyaris setiap menit hidup anaknya dengan kursus-kursus, program sosialisasi, dan kegiatan-kegiatan "pengayaan" lainnya. Kedua, menuntut prestasi tinggi di sekolah dan di berbagai bidang lain, nyaris dengan segala cara (emosional, psikologis, fisik, dan dana). Ketiga, menekan anak memilih kursus, pelatihan, atau minat lebih untuk tujuan membuat CV (Curriculum Vitae) atau Daftar Riwayat Hidup yang mengesankan daripada untuk memenuhi rasa ingin tahu yang alamiah dan minat pribadi. Keempat, mencampuri persahabatan dan hubungan anak dengan guru dan pelatihnya.

Para orang tua yang menerapkan push parenting berasumsi bahwa anak-anak tidak akan berhasil dalam kehidupan mereka kelak, kalau orangtua tidak "membantu" mereka sepenuhnya. Anak-anak dianggap sama sekali tidak mampu memutuskan sendiri pilihan yang bertanggung jawab demi masa depan mereka 
sendiri. Sehingga orang tua merasa harus memilih apa yang menurut mereka terbaik untuk anak mereka, dan anak pun harus mengikutinya, walaupun kemungkinan besar dengan terpaksa, atau tidak tahu dasar pemilihan yang dilakukan oleh orangtua mereka, karena anak-anak memang belum secara matang mengetahui secara tepat sesuatu itu akan bermanfaat atau tidak bagi mereka. Meskipun demikian, pada dasarnya, tidak ada orangtua yang dengan sengaja mematikan bakat anak-anak mereka. Kebanyakan orang tua yang menerapkan push-parenting tersebut dikarenakan kurangnya pemahaman yang mendalam tentang bagaimana dampak pola asuh tersebut terhadap tumbuh kembang, khususnya sosial-emosional, anak-anak mereka (Lidanial, 2006).

\section{Mengenalkan Agama pada Anak}

Salah satu tugas orang tua adalah mengenalkan pendidikan agama pada anak. Pentingnya penanaman nilai-nilai agama sejak usia dini untuk membekali anak dalam menghadapi perjalanan kehidupannya sangat disadari oleh Maharaja Bikrama Bispa. Untuk itu, ia mendatangkan guru agama untuk Indraputra. Pelajaran agama yang utama untuk ditekankan oleh Maharaja Bikrama Bispa pada anaknya adalah kemampuan membaca kitab suci Alquran.

"Hatta setelah berapa lamanya, maka anakanda baginda Indraputra pun besarlah, maka disuruhkan baginda kepada mualim disuruh ajar mengaji. Setelah berapa lamanya kira-kira tujuh tahun umur Indraputra, maka Indraputra pun tahulah mengaji Quran" (Mulyadi, 1983).

Dalam kutipan di atas, Indraputra di saat umur tujuh tahun, sudah cukup mahir membaca Alquran. Artinya, Indraputra sudah belajar Alquran sebelum berumur tujuh tahun. Bisa diperkirakan, Maharaja Bikrama Bispa mendatangkan guru Alquran dua atau tiga tahun sebelum Indraputra mencapai usia tujuh tahun. Usia ini sangat ideal untuk mengenalkan Alquran untuk anak.

Menanamkan rasa cinta kepada Alquran memang seharusnya dilakukan oleh orang tua pada anaknya sejak usia dini karena tahun-tahun pertama usia anak merupakan masa pembentukan watak. Jika pengenalan terhadap Alquran telah ditanamkan sejak usia dini, hal itu akan menumbuhkan kecintaan anak terhadap Alquran yang pada gilirannya akan lebih membekas pada jiwa anak dan akan berpengaruh dalam kehidupannya, baik saat ini maupun selanjutnya.

Belajar membaca Alquran pada konteks ini bisa dimaknai dengan belajar membaca pada umumnya. Ini merupakan proses kemampuan membaca permulaan di usia dini. Kemampuan membaca permulaan merupakan kemampuan membaca anak pada tingkat awal dengan mengenal dan membaca simbol-simbol huruf untuk dibunyikan, bukan untuk memahami pesan dari apa yang dibacanya. Inilah fase pertama dalam keterampilan berbahasa. Karena kemampuan membaca merupakan sebuah proses, memang seharusnya kemampuan membaca itu sudah dilakukan sejak usia dini. Makin muda usia anak dalam belajar membaca, makin mudah bagi anak untuk dapat membaca dengan lancar.

Ada lima tahap perkembangan kemampuan membaca pada anak, yaitu tahap magis, tahap konsep diri, tahap membaca peralihan, tahap membaca lanjut, dan tahap membaca mandiri. Pada tahap magis, anak mulai suka membolak-balikkan buku yang terlihat saat anak berusia dua tahun. Pada tahap konsep diri, anak 
menganggap dirinya sudah dapat membaca, padahal belum, yang terlihat saat anak berusia tiga tahun. Pada tahap membaca peralihan, anak mulai mengingat huruf atau kata yang terlihat saat anak berusia empat tahun. Pada tahap membaca lanjut, anak mulai mengeja dan membaca kata yang terlihat saat anak berusia lima tahun. Pada membaca mandiri, anak sudah dapat membaca buku dan mencoba memahami makna dari apa yang ia baca yang terlihat saat anak berusia 6-7 tahun (Suyanto, 2005).

Nilai agama dan moral merupakan satu dari enam aspek perkembangan anak usia dini yang harus mendapatkan stimulasi dari lingkungannya (A'yun, Prihartanti, \& Chusniatun, 2016). Penanaman nilai-nilai agama dan moral akan memberikan pijakan kepribadian yang kuat yang akan menjadi bekal anak hidup di era dimana moral mulai jarang diperbincangkan oleh masyarakat (Inawati, 2017). Tak hanya memberikan stimulasi bagi aspek kognitifnya, Maharaja Bikrama Bispa menjadikan stimulasi nilai agama dan moral sebagai prioritas untuk tumbuh kembang putranya. Hal demikian pun seharusnya dilakukan oleh para orang tua di era modern seperti sekarang. Agama akan menanamkan iman yang benar yang akan menjadi pemandu jalan hidup seorang anak mencapai jati dirinya.

\section{Memberikan Stimulasi pada Anak}

Suatu ketika, Maharaja Bikrama Bispa mendapat hadiah dari dua orang utusan dari kerajaan bawahan untuk menyerahkan upeti. Kedua utusan itu memberikan hadiah sesuai dengan keahliannya masing-masing. Tukang kayu memberikan ukiran ikan kayu dan tukang emas memberikan ukiran burung Merak Emas. Ikan kayu dimasukkan di wadah yang berisi air dan burung Merak Emas ditempatkan di sebuah baki yang terbuat dari emas juga (Mulyadi, 1983).

Ikan kayu dan burung emas menjadi daya tarik tersendiri bagi Indraputra. Ia terlihat amat menyukai keduanya. Karena itu, tanpa menghiraukan ayahnya yang masih terlibat pembicaraan dengan tamunya, Indraputra langsung turun dari pangkuan Maharaja Bikrama Bispa untuk mendekati binatang imitasi tersebut.

"Hatta setelah berapa lamanya dalam antara berkata-kata itu maka Indraputra turun daripada ribaan ayahanda baginda itu melihat merak 6 emas itu mengigal, duduk hampir sisi talam itu" (Mulyadi, 1983).

Walaupun tanpa disadari oleh Maharaja Bikrama Bispa, kehadiran binatang imitasi itu merupakan bentuk stimulasi bagi anaknya. Setidaknya, rangsangan visual telah dilakukan oleh Mahajara Bikrama Bispa untuk membuat Indraputra secara mandiri menghampiri keberadaan objek yang menjadi daya tariknya.

Dari sana, disadari bahwa anak yang memiliki tumbuh kembang yang optimal adalah dambaan setiap orang tua. Untuk mewujudkannya, orang tua harus memberikan stimulasi pada anaknya. Stimulasi adalah rangsangan yang bersumber dari lingkungan anak. Anak yang mendapat stimulasi yang terarah akan lebih cepat berkembang dibandingkan anak yang kurang. Pelbagai macam stimulasi, seperti stimulasi visual (penglihatan), verbal (bicara), auditif (pendengaran), taktil (sentuhan), dan sebagainya dapat mengoptimalkan perkembangan anak (Kania, 2006). Dalam hal yang lebih konkret, objek stimulasi dalam pendidikan anak usia dini dikenal dengan enam aspek perkembangan anak, yaitu meliputi aspek 
perkembangan kognitif, bahasa, sosial emosional, seni, nilai agama dan moral, serta fisik motorik.

Istilah tumbuh kembang sebenarnya mencakup dua peristiwa yang sifatnya berbeda, tetapi saling berkaitan dan sulit dipisahkan, yaitu pertumbuhan dan perkembangan. Pertumbuhan berkaitan dengan masalah perubahan dalam besar, jumlah, atau ukuran, yang bisa diukur dengan ukuran berat (gram, kilogram) dan ukuran panjang ( $\mathrm{cm}$, meter), sedangkan perkembangan adalah bertambahnya kemampuan dalam struktur dan fungsi tubuh yang lebih kompleks dari seluruh bagian tubuh sehingga masing-masing dapat memenuhi fungsinya. Dalam hal ini, termasuk juga perkembangan emosi, intelektual, dan tingkah laku sebagai hasil berinteraksi dengan lingkungannya (Kania, 2006).

Stimulasi yang disediakan oleh Maharaja Bikrama Bispa untuk Indraputra dapat disebut alat permainan edukasi (APE). Bermain memang identik dengan aktivitas yang memberikan kesenangan kepada anak (Hastuti, 2009). Bermain ialah suatu kegiatan yang menyenangkan yang dilaksanakan untuk kepentingan kegiatan itu sendiri. Kegiatan tersebut dilakukan tanpa paksaan dan dengan perasaan senang (Santrock, 2002).

Bermain umumnya membutuhkan alat permainan. Tidak sekadar alat permainan tanpa makna, tetapi permainan yang mengandung nilai pendidikan yang dikenal dengan alat permainan edukasi (APE). Permainan edukatif adalah permainan yang memiliki unsur mendidik yang didapatkan dari sesuatu yang ada dan melekat serta menjadi bagian dari permainan itu sendiri (Rahmawati, 2013). Selain itu, permainan juga memberi rangsangan atau respons positif terhadap indra pemainnya. Indra yang dimaksud adalah pendengaran, penglihatan, suara (berbicara, komunikasi) (Wati, 2019), menulis, daya pikir, keseimbangan kognitif, motorik (keseimbangan gerak, daya tahan, kekuatan, keterampilan, dan ketangkasan), afeksi (Ramadhan Lubis, 2018), serta kekayaan sosial dan spritual (budi pekerti luhur, cinta, kasih sayang, etika, kejujuran, tata krama dan sopan santun, persaingan sehat, serta pengorbanan). Keseimbangan indra ini harus direncanakan agar memengaruhi jasmani, nalar, imajinasi, watak dan karakter, sampai tujuan pendewasaan diri anak.

Walaupun penting bagi tumbuh kembang anak, perlu diperhatikan bahwa tidak semua jenis stimulasi mempunyai daya efektivitas yang sama. Anak-anak yang mendapat stimulasi yang sama bisa saja menunjukkan hasil yang berbeda. Pelbagai parameter stimulasi perlu dipertimbangkan, termasuk jumlah, tipe, pola, kualitas, atau faktor-faktor risiko yang akan muncul (Howell C, Rauh VA, 1990).

\section{Menjaga Kebersihan Anak}

Sebagaimana kita ketahui, Indraputra diterbangkan burung Merak Emas dan dijatuhkan di kebun milik Nenek Kebayan. Tidak beberapa lama kemudian, Nenek Kebayan pun menemukan Indraputra di kebunnya. Nenek Kebayan heran karena ada anak bisa berada di kebunnya, padahal kebun itu terkunci dan cukup jauh dari perkampungan.

Nenek Kebayan akhirnya bisa mengetahui semuanya dari sedikit penjelasan dari Indraputra. Ia pun memakluminya. Indraputra pun dianggap sebagai cucunya dan dibawa pulang ke rumahnya. Ia memperlakukan Indraputra bagai cucunya sendiri. Indraputra dimandikan dan disuruhnya untuk berganti pakaian. 
“Maka nenek kebayan pun suka hatinya lalu dimandikannya Indraputra, maka dibawanya pulang ke rumahnya dan dikeluarkannya segala pakaiannya daripada tubuh Indraputra, ditaruh nenek kebayan, maka diberinya pakaian yang lain" (Mulyadi, 1983).

Nenek Kebayan menyadari bahwa Indraputra baru saja melakukan perjalanan jauh. Tentunya, tubuh dan pakaiannya telah menjadi kotor. Apalagi, Indraputra dijatuhkan di perkebunan, tepatnya perkebunan buah delima miliknya. Indraputra sebagai seorang anak kecil tidak akan memperdulikan hal itu. Orang dewasalah yang mampu memahami keadaan demikian. Dalam hal ini, orang dewasa itu adalah Nenek Kebayan. Sesuatu yang sewajarnya, jika ia memandikan Indraputra dan mengganti pakaian Indraputra.

Kebersihan merupakan unsur utama dalam mewujudkan kesehatan, terutama kesehatan diri anak usia dini. Kesehatan diri sangat dibutuhkan dalam meningkatkan pertumbuhan dan perkembangan anak. Kesehatan diri adalah kebersihan anggota tubuh dan pakaian. Kegiatan untuk menjaga kebersihan adalah mandi, keramas, kebersihan telinga, perawatan gigi, mencuci tangan, kebersihan kaki, dan ganti baju (Dini, 2011).

Kesehatan diri pada dasarnya adalah kegiatan harian. Ini perlu pembiasaan. Pembiasaan membutuhkan pendampingan dan pembinaan dari orang dewasa, dalam hal ini adalah orang tua anak. Orang tua sangat dibutuhkan untuk optimalisasinya. Hal ini dilakukan agar tumbuh kembang anak dapat berjalan secara wajar.

Jika pembiasaan kesehatan diri anak berjalan optimal, anak akan memiliki perilaku sehat. Perilaku adalah kegiatan yang dilakukan oleh individu (seseorang), baik yang dapat diamati (dilihat) secara langsung maupun tidak langsung. Sehat adalah suatu kondisi atau keadaan yang baik yang mencakup fisik, mental, dan sosial. Sehat tidak hanya terbebas dari penyakit. Dengan demikian, perilaku sehat adalah tindakan seseorang atau kegiatan yang dilakukan oleh seseorang, baik langsung maupun tidak langsung, untuk mempertahankan dan meningkatkan kesehatannya serta mencegah risiko penyakit (Dini, 2011).

Jika pembiasaan perilaku sehat anak usia dini sudah berjalan terus-menerus dan anak sudah tidak lagi membutuhkan pengawasan dari orang tua, anak ini telah memiliki pola hidup sehat. Dengan pola hidup sehat, mereka terbebas dari serangan pelbagai macam penyakit yang sering terjadi pada anak usia dini, seperti batuk/pilek, flek atau TBC, diare, demam, campak, infeksi telinga, dan penyakit kulit.

\section{Membahagiakan Anak}

Anak adalah anugerah dari Tuhan kepada kedua orang tua. Kehadiran anak sejatinya merupakan kebahagiaan bagi orang tua. Orang tua sudah bahagia dengan itu. Di pihak lain, anak juga membutuhkan rasa bahagia. Kebahagiaan anak tidak cukup dengan kehadiran orang tua yang selalu ada di sisinya. Kebahagiaan anak justru bersumber dari pengasuhan orang tuanya atau cara orang dewasa memperlakukannya.

Setelah dijatuhkan oleh burung Merak Emas di kebun milik Nenek Kebayan, Indraputra menyadari bahwa ia jauh dari orang tuanya. Ia merindukan keduanya. Indraputra bersedih hati. Untungnya, Indraputra ditemukan oleh Nenek Kebayan 
dan yang paling menggembirakan hatinya adalah Nenek Kebayan memperlakukan dirinya seperti cucu Nenek Kebayan sendiri. Nenek Kebayan ini setiap harinya selalu berjualan bunga di pasar. Nenek Kebayan memperkenalkan Indraputra sebagai cucunya kepada setiap orang yang ditemuinya. Cucu yang baru bisa bepergian karena sebelumnya masih terlalu kecil (Mulyadi, 1983). Perlakuan inilah yang membuat Indraputra bahagia dan dapat melupakan kesedihannya.

Kebahagiaan lain yang didapat oleh Indraputra adalah perlakukan orang lain terhadap dirinya saat ia menyertai Nenek Kebayan untuk berjualan bunga. Banyak orang yang memberikan sesuatu untuk Indraputra sebagai bentuk kasih sayang kepada dirinya. Sebagai anak, jika diberi sesuatu oleh orang dewasa, pasti akan merasa senang dan bahagia.

“... ada yang memberi pakaian daripada seorang kepada seorang. Demikianlah peri orang kasih akan Indraputra itu, barang siapa memandang muka Indraputra itu tiada lupa daripada hatinya" (Mulyadi, 1983).

Selain Nenek Kebayan, ada satu orang lagi yang menganggap Indraputra sebagai keluarganya, yaitu perdana menteri dari kerajaan yang dirajai oleh Raja Syahsyian, negeri yang ditempati oleh Indraputra. Pertemuan Indraputra dengan perdana menteri tatkala Indraputra mendampingi Nenek Kebayan untuk mengantarkan bunga ke rumah sang perdana menteri. Perdana menteri mengamati Indraputra hingga akhirnya ia berkehendak untuk mengambil Indraputra sebagai anaknya. Untuk memperlihatkan niat baiknya, perdana menteri pun mengajak Indraputra makan bersama, bahkan dalam satu hidangan. Sikap akrab yang diperlihatkan oleh perdana menteri ini cukup membahagiakan Indraputra karena ia merasa nyaman dan damai berdekatan dengan sang perdana menteri.

“... Maka perdana menteri hendak makan nasi maka diajaknya akan Indraputra makan sama-sama sehidangan. Tiada Indraputra mau makan sehidangan perdana menteri, maka dipegang perdana menteri tangan Indraputra dibawanya makan samasama" (Mulyadi, 1983).

Secara sekilas, bahagia dan senang itu mempunyai makna yang sama. Bahagia berbeda dengan senang. Senang itu bagian dari bahagia, tetapi bahagia bukan bagian dari senang. Orang yang bahagia, bisa dipastikan ia juga senang. Akan tetapi, orang yang terlihat senang, belum tentu ia bahagia. Secara filsafat, bahagia dapat dimaknai sebagai kenyamanan dan kenikmatan spiritual sehingga merasa tenang dan damai. Kebahagiaan bersifat abstrak dan tidak dapat disentuh atau diraba. Kebahagiaan erat hubungannya dengan kejiwaan yang bersangkutan (Seligman, 2004).

Setiap orang tua ingin anaknya terlihat bahagia. Membahagiakan anak adalah keinginan setiap orang tua (Roesli, Syafi, \& Amalia, 2018). Banyak orang tua beranggapan bahwa mainan anak dapat membuat anak bahagia. Padahal, itu tidak sepenuhnya benar. Jika mainan itu dimaksudkan sebagai media stimulasi, hal ini bisa dibenarkan, tetapi belum tentu membahagiakan anak. Hal ini digambarkan saat Indraputra dalam petualangannya menemani anak raja-raja jin bermain seraya makan buah-buahan setelah anak raja-raja jin mandi di danau. 
"Maka segala anak raja-raja itu semuanya bermain makan buah-buahan dengan Indraputra. Setelah sudah maka Indraputra pun bermohonlah kepada segala anakanak raja itu lalu berjalan. Maka segala anak raja-raja jin itu semuanya pulang masingmasing ke negerinya kepada ayah bundanya"(Mulyadi, 1983).

Membahagiakan anak tidak membutuhkan sesuatu apa pun. Mendampingi anak saat bermain atau selalu hadir saat mereka membutuhkan keberadaan orang tua adalah sesuatu yang sangat berharga bagi mereka dan itu sudah membuat mereka berbahagia, membuat mereka damai dan nyaman. Membahagiakan anak sesungguhnya adalah upaya untuk memastikan segala kebutuhan anak terpenuhi, yaitu meliputi kebutuhan asuh, asih, dan asah. Kebahagiaan adalah modal dasar bagi anak untuk membangun kepercayaan dan optimisme terhadap dunia sekitarnya, serta landasan bagi tumbuhnya kepercayaan diri.

\section{Mendoakan Anak}

Indraputra adalah anak Maharaja Bikrama Bispa satu-satunya. Ia adalah pewaris kerajaan sepeninggal dirinya. Saat Indraputra diculik oleh burung Merak Emas, Maharaja Bikrama Bispa sangat bersedih. Ia sangat kehilangan anaknya.

“Selama Indraputra hilang diterbangkan merak emas itu Raja Bikrama Bispa tiada duduk dalam istana, hanya duduk dalam masjid juga dengan segala pendeta, berbuat ibadat dan minta doa kepada Allah Taala, supaya bertemu dengan anakda baginda Indraputra"(Mulyadi, 1983).

Dari kutipan di atas, tergambar kesedihan Maharaja Bikrama Bispa. Sejak Indraputra hilang, Maharaja Bikrama Bispa sering meninggalkan istana. Ia selalu berada di masjid yang temani oleh para penghulu agama. Ia beribadah dan berdoa kepada Allah Taala supaya dapat bertemu dengan anaknya kembali. Kisah ini terdapat pada bagian akhir dari HI. Walaupun demikian, bagian cerita ini dapat dimasukkan dalam pengasuhan anak usia dini karena kesedihan Maharaja Bikrama Bispa sejak Indraputra dinyatakan hilang di usia tujuh tahun.

Setiap orang tua pasti mempunyai harapan besar terhadap kebaikan anaknya dan berharap agar anak mereka menjadi pribadi yang baik. Para orang tua pasti menginginkan anak mereka tumbuh menjadi pribadi yang cerdas, saleh, berbakti, dan bijaksana. Ini bisa diusahakan lewat didikan keluarga. Selain itu, usaha lain yang sangat penting bagi orang tua adalah mendoakan anak agar kebaikan yang diinginkan dari sang anak bisa tercapai. Doa dari orang tua mempunyai pengaruh yang besar bagi kebaikan seorang anak. Untuk itu, mendidik anak agar anak yang sesuai harapan keluarga akan menjadi lebih sempurna jika didampingi dengan doa, mendoakan anak di mana pun dan kapan pun.

Dalam mendoakan anak, orang tua harus berhati-hati agar tidak mendoakan keburukan bagi anak karena justru akan menghasilkan keburukan bagi anak, apapun kondisinya. Doa keburukan bagi anak hanya akan menambah pembangkangan, kerusakan, dan kedurhakaan. Boleh jadi, bertambahnya kedurhakaan seorang anak disebabkan oleh faktor doa orang tua yang mengharapkan keburukan untuk anaknya, walaupun tanpa disengaja. Lazimnya, orang yang melontarkan doa keburukan bagi anaknya adalah orang tua yang tidak mampu menahan kemarahan saat melihat perilaku anaknya yang dianggap 
bermasalah. Dalam situasi ini, orang tua akan tergesa-gesa dan tanpa pikir panjang mengeluarkan doa yang semestinya tidak diucapkan oleh orang tua bagi anaknya.

\section{SIMPULAN}

Bentuk pengasuhan Indraputra yang dilakukan oleh orang tuanya secara langsung dalam konteks anak usia dini dari mulai kelahirannya hingga usia tujuh tahun. Dalam periode ini, pengasuhan yang dapat ditemukan adalah bersukacita atas kelahiran anak, memberi nama yang baik pada anak, memberi perlindungan pada anak, bersyukur atas kelahiran anak, mengenalkan agama pada anak, dan mendoakan anak, sedangkan pengasuhan dalam menjaga kebersihan anak dan membahagiakan anak ditemukan saat Indraputra dalam pengasuhan Nenek Kebayan dan perdana menteri kerajaan yang dirajai oleh Raja Syahsyian. Pengasuhan anak usia dini tidak hanya ditemukan pada cerita Indraputra, tetapi juga ditemukan pada cerita pengasuhan Raja Syahsyian terhadap putrinya yang bernama Tuan Putri Mengindra Sari Bunga. Pengasuhan yang dapat ditemukan dalam cerita Raja Syahsyian adalah bersukacita atas kelahiran anak, memberi nama yang baik pada anak, memberi perlindungan pada anak, dan bersyukur atas kelahiran anak.

\section{UCAPAN TERIMAKASIH}

Alhamdulillaah, segala puji bagi Allah SWT, atas nikmat hidayah dan taufiqNya penulis dapat menyelesaikan seluruh rangkaian proses penelitian, mulai dari perumusan masalah hingga penyusunan laporan hasil penelitian. Terima kasih penulis sampaikan kepada semua pihak yang telah membantu terselesaikannya penelitian ini dari awal hingga akhir. Tentu masih terdapat kekurangan di sana sini yang masih membutuhkan perbaikan, baik dalam persiapan, peleksanaan hingga penyusunan laporannya. Penulis terbuka dalam menerima kritik dan saran untuk pengembangan kajian ini ke arah yang lebih baik. Semoga hasil kajian ini dapat memberikan manfaat bagi masyarakat luas para pemerhati, peminat, peneliti serta praktisi pendidikan anak usia dini. Amin.

\section{DAFTAR PUSTAKA}

A.K., M. (2000). Materi Pokok Fiqih II. Jakarta: Direktorat Jenderal Pembinaan Kelembagaan Islam dan Universitas Terbuka.

A'yun, Q., Prihartanti, N., \& Chusniatun, C. (2016). Peran Orangtua dalam Pendidikan Anak Usia Dini (Studi Kasus pada Keluarga Muslim Pelaksana Homeschooling). Indigenous: Jurnal Ilmiah Psikologi.

Abdullah, I. T. (1998). Hikayat Meukuta Alam, Suntingan Teks dan Terjemahan beserta Telaah struktur dan Resepsinya. Universitad Gadjah Mada.

Balswick, J. O., \& Balswick, J. K. (2014). The family: a Christian perspective on the contemporary home. USA: Baker Academic a Devision of Baker Publishing Group.

Berns, R. (2012). Child, Family, School, Community: Socialization and Support. USA: Cengage Learning.

Braginsky, V. I. (1993). The System of Classical Malay Literature. Leiden: KITLV Press.

Braginsky, V. I. (1998). Yang Indah, Berfaedah, dan Kamal: Sejarah Sastra Melayu dalam Abad 7-19. Jakarta: INIS. 
Dini, D. P. P. A. U. (2011). Mengembangkan Perilaku Sehat pada Anak Usia 2-4 Tahun. Jakarta: Direktorat Jenderal Pendidikan Anak Usia Dini Nonformal dan Informal, Kementerian Pendidikan Nasional.

El-Firdausy, M. I. (2009). Dahsyatnya Sedekah (Meraih Berkah dari Sedekah). Yogyakarta: Cemerlang Publising.

Fadilla, N. (2018). Upaya Perlindungan Hukum terhadap Anak sebagai Korban Tindak Pidana Perdagangan Orang. Jurnal Hukum Dan Peradilan, 5(2), 181. https:/ / doi.org/10.25216/jhp.5.2.2016.181-194

Fang, L. Y. (1982). Sejarah Kesusastraan Melayu Klasik. Singapura: Pustaka Nasional.

Hastuti, D. (2009). "Stimulasi Psikososial pada Anak Kelompok Bermain di Kota Bogor dan Pengaruhnya pada Perkembangan Motorik, Kognitif, Sosial Emosi dan Moral/Karakter Anak." Jurnal Ilmu Keluarga Dan Konsumen, 2(1), 41-56. https:/ / doi.org/10.24156/jikk.2009.2.1.41

Hidayati, L. (2016). Stop! Push-Parenting: Shoot Parent's Ambition as Kind of Psychological Abuse in Parenting. Indonesian Journal of Islamic Early Childhood Education, 1(1), 9-16.

Hidayati, Z. (2010). Anak Saya Tidak Nakal. Yogyakarta: Bintang Pustaka.

Howell C, Rauh VA, N. B. dan A. T. (1990). Motherinfant transaction program dalam "Stimulation and the preterm infant" Lester BM, Tronick EZ, penyunting. Clin Perinatol.

Inawati, A. (2017). Strategi Pengembangan Moral dan Nilai Agama Untuk Anak Usia Dini | Al-Athfal : Jurnal Pendidikan Anak. Retrieved January 8, 2020, from AlAthfal: Jurnal Pendidikan Anak website: http://ejournal.uinsuka.ac.id/tarbiyah/index.php/alathfal/article/view/1422

Istanti, K. Z. (2013). Unsur Kepahlawanan Hikayat Indraputra. Jurnal Humaniora, 0(2). https:/ / doi.org/10.22146/jh.2097

Kania, N. (2006). Stimulasi Tumbuh Kembang Anak untuk Mencapai Tumbuh Kembang yang Optimal. Bandung.

Lidanial. (2006). Anak Korban Orangtua Ambisius Push Parenting dan Konseling Terhadapnya. Jurnal Veritas, 283-299. https://doi.org/10.36421/veritas.v7i2.178.

Ma'rifat, D. F. (2019). Studi Bandingan Dua Cerita dalam Manuskrip Nus. Prosiding Seminar Kebahasaan Internasional, 759-765. Jakarta: Badan Bahasa Kemdikbud.

Mansur, H. (2009). Psikologi Ibu dan Anak untuk Kebidanan. Jakarta: Salemba Medika.

Mulyadi, S. W. R. (Sri W. R. (1983). Hikayat Indraputra : a Malay romance. Netherlands: Foris Publications.

Nirwana, A. B. (2011). Psikologi Kesehatan Wanita. Yogyakarta: Muha Medika.

Purnama, S. (2016). Elements of Child-Friendly Environment: The Effort to Provide an Anti-Violence Learning Environment. Indonesian Journal of Islamic Early Childhood Education, 1(1), 131-140.

Purnama, S. (2018). Pengasuhan Digital untuk Anak Generasi Alpha. Al Hikmah Proc Islamic Ear Child, 493-502. Retrieved from https://www.academia.edu/download/57365843/Pengasuhan_Digital_48_Si git_Purnama_493-502.pdf

Rahman, F. (2010). Pintar Ibadah. Surabaya: Pustaka Media.

Rahmawati, F. M. dan N. (2013). Metode Permainan-Permainan Edukatif dalam Belajar Bahasa Arab. Yogyakarta: Diva Press.

Ramadhan Lubis, K. (2018). Permainan Tradisional sebagai Pengembangan 
Kecerdasan Emosi Anak. Al-Athfal: Jurnal Pendidikan Anak, 4(2), 177-186. https://doi.org/http://dx.doi.org./10.14421/al-athfal.42-05

Roesli, M., Syafi, A., \& Amalia, A. (2018). Kajian Islam Tentang Partisipasi Orang Tua Dalam Pendidikan Anak. Jurnal Darussalam; Jurnal Pendidikan, Komunikasi Dan Pemikiran Hukum Islam, IX(2), 2549-4171.

Santrock, J. W. (2002). Life-Span Development. New York: McGraw-Hill Companies, Inc.

Seligman, M. E. P. (2004). Authentic Happines. New York: free press.

Sholeh, M. K. (2003). Buku panduan Manajemen Masalah Bayi Baru Lahir untuk Dokter, Bidan, dan Perawat di Rumah Sakit. Jakarta: IDAI Depkes RI.

Sobur, A. (1991). Psikologi Umum. Bandung: Pustaka Setia.

Suhardjo. (1996). Berbagai Cara Pendidikan Gizi. Jakarta: Bumi Aksara bekerja sama dengan Pusat Antar universitas Pangan dan Gizi Institut Pertanian Bogor.

Suyanto. (2005). Konsep Dasar Anak Usia Dini. Retrieved from http://journals.ums.ac.id/index.php/indigenous/article/view/2601

Wati, H. R. (2019). Stimulasi Kemampuan Berbicara Anak di PAUD Solok Selatan Sejahtera. Golden Age: Jurnal Ilmiah Tumbuh Kembang Anak Usia Dini, (2), 51-60. Retrieved from http://ejournal.uinsuka.ac.id/tarbiyah/index.php/goldenage/article/download/2555/1654

Winstedt, R. O. (1920). The Date of the Hikayat Inderaputera. JSBRAS: LXXXII. 